\title{
The Blue Ocean Strategy Analysis of Chrysanthemum Flower
}

\author{
Venty Fitriany Nurunisa ${ }^{1, *}$, and Karina Triani Dewi ${ }^{2}$ \\ ${ }^{1}$ Universitas Terbuka, Agribusiness Program, Pondok Cabe, Tangerang Selatan, Indonesia \\ ${ }^{2}$ Universitas Surya, Agribusiness Program, Grand Serpong Mall Lt. 1 Unit F8 \& F9, Tangerang, \\ Indonesia
}

\begin{abstract}
West Java as the central production of flower commodity in Indonesia is supported by 9 central districts, which Cianjur, one of the top three, contributes $53.67 \%$ of the West Java flower production. A high competition within the flower businesses result a growing issue for PT Alam Indah Bunga Nusantara (Alinda) as one of Chrysanthemum business leader in Cianjur. Thus, the company considers a more relevant strategy which makes this research aims on examining a) the competition factors, b) company's industrial situation, and c) different business strategy by using the Blue Ocean Strategy approach. Exploratory sequential mixed method was conducted. The analysis shows that PT Alinda need to reconstruct the market boundaries, consider new potential market through product differentiation. PT Alinda need to rebuild the consumer value by eliminate the payment negotiation service factor, reduce the product quality assurance factor, increase the order ease factor, and create a new business line such as offering flower arrangements and dried flower handicrafts. The third step of the strategy formulation aims to maximize strategy formulation for non-consumer markets. Furthermore, the Blue Ocean Strategy testing should be focused on the underperforming factors.
\end{abstract}

\section{Introduction}

The growth of ornamental plants including floriculture business is considerably positive in Indonesia. Especially in the last two years, the business growth is also triggered by Pandemi Covid 19 [1]. Ornamental plants are used to increase the landscape beauty [2]. Furthermore, the diversity of ornamental plants used in landscape area, could also contribute to biodiversity conservation and become a potential tourist attractions [3]. Ornamental plants are categorized in a form of cut flowers, ornamental plants in pots, and other ornamental plant. The most produced ornamental plants in Indonesia are Chrysantemum, which reaches $480,685,420$ stalk of flower or about 58 percent of the total ornamental plants productions, followed by the production of rose and tuberose [4]. Chrysanthemum is produced to fulfill the needs of domestic domestic and export market. Moreover, fresh cut chrysanthemums are the most exported floriculture commodity from Indonesia.

\footnotetext{
*Corresponding author : venty@ecampus.ut.ac.id
} 
There are three largest producers of chrysanthemum in Indonesia, West Java, East Java, and Central Java [3]. West Java province is the largest producer of Chrysantemum which production reaches 187,322,207 stalk of flower [3]. Cianjur district is one of Chrysantemum central production in West Java province. Cianjur contributes $53.67 \%$ of the West Java flower production, while followed by West Bandung Regency $24.75 \%$ and Sukabumi Regency at $20.69 \%$ [5]. Chrsysanthemum is the most exported ornamental plants, in 2018 export volume of Chrysantemum increased from 49.52 tons to 59.11 tons, with FOB value increased from USD 699,176 to USD 817,208 [4].

PT Alam Indah Bunga Nusantara (PT Alinda) is a company engaged in the cultivation of several ornamental plants, including Chrysanthemums, Carnations, and other potted plants since 1989. The land area owned by the company is 8 hectares with productive land currently covering 3.5 hectares. PT Alinda distributes Chrysantemums not only to domestic market, but also to target the export market. Along with the company development, in the last years the company has encountered obstacles in producing cut Chrysanthemum with standardized and good quality due to no longer supportive environmental and building conditions. Those conditions resulting low quality of Chrysantemum products, which often caused rejection from the export market even from the domestic market.

Moreover, in Cianjur itself competition between similiar company and even farmers are very tight. It is recorded that there are 46 ornamental plants producers which also produce Chrysanthemum in Cianjur [5]. Moreover, PT Alinda also facing a tight price competition especially in marketing to six markets in Jakarta, PT Alinda has to compete with farmers which selling price is cheaper than the selling price of PT Alinda's Chrysanthemum. A high competition within the flower businesses result a growing issue for PT Alam Indah Bunga Nusantara (Alinda) as one of Chrysanthemum business leader in Cianjur. This conditions requires every business actor to develop an appropriate and feasible strategy, so that the strategy can win the competition.

Generally, in conditions of many competitors or known as red oceans, business actors or companies beat opponents in order to obtain greater demand by competing with each other. An industry in a crowded market space, then the prospect of profit and growth will decrease [6]. Therefore, a development strategy is needed in order to prevent a decline in profit prospects, even worse. One strategy that can be used when facing very tight competition is to apply a blue ocean strategy. Blue ocean strategy makes the competition. This is characterized by creating untapped market space, creating demand, as well as profitable growth opportunities. Blue ocean strategy does not focus on winning the competition, but more on uses strategic logic (value innovation). The value innovation aims to generate a leap in value for buyers and businesses themselves. The difference between creating a blue ocean strategy (BOS) with other is that in BOS the company can not only increase the existing market, but also try to create a market from non-consumers in the industry, so that the company can create new demand.

Based on the background described above, the objectives of this research are to analyze the competition factor of Chrysanthemum industry and analyze the blue ocean strategy for PT Alinda.

\section{Literature review}

\subsection{Red ocean strategy}

Competitors, consumer preferences, social changes, technological advances are constantly changing. Those changes generate market boundaries which next is called Red Ocean [6]. In the red ocean, the boundaries that exist in the market are known and accepted, and the 
rules of competition are known to each other. In this condition, the company is trying hard to fight against its competitors to increase the market share even more. When the conditions in the market are too crowded, profit gains in an industry will tend to decline and sales growth will be difficult to increase [6]. So that the atmosphere of competition will be tighter and turn the red ocean into an ocean full of blood because companies must compete very hard to win the competition to have a strong position.

Red ocean is a term for an industry with defined and accepted boundaries; even competitors' rules can be known. Thus, the competition against each company will be very high. Generally, there are several theories that discuss alternative business strategies that may be applied to companies in red ocean conditions, one of which is competitive strategy. The purpose of this strategy is to determine the position in the industry, so that the company can protect itself safely from the existing pressures or the company can influence the pressure well on the industry. Generally, business strategies that are in red ocean conditions will choose between a low-cost position and differentiation in competition.

\subsection{Blue Ocean Strategy}

Blue Ocean is the opposite of Red Ocean. In this case, blue ocean strategy is a strategy that focuses on exploring industries or markets that have never been explored or have never been discovered by competitors. Basically, company in red ocean condition is more likely to adapt the conventional approach by strengthening their position to win the competition. Meanwhile, Blue Ocean does not focus on competition in running their business but more to value innovation from the products created. But before that, there are six principles in creating a blue ocean strategy that must be done.

The first principle in the formation of a blue ocean strategy is to reconstruct market boundaries. In this principle, managers are challenged to identify blue ocean opportunities that are considered attractive for commercialization. When this opportunity idea is found, it can then be applied or mapped on the strategy canvas so that a good strategy can be generated. The second principle is to focus on the bigger picture, not the numbers. This principle brings the company closer to the development of alternatives to an existing strategic planning process by clearly describing the industry conditions and the current competitive situation in the market which can then be discussed how the company increases market share, captures new segments, or cuts costs that have been so far has been overexploited.

Tabel 1. Difference between red ocean strategy and blue ocean strategy

\begin{tabular}{|l|l|}
\hline \multicolumn{1}{|c|}{ Red ocean strategy } & \multicolumn{1}{c|}{ Blue ocean strategy } \\
\hline Competing in an existing market space & $\begin{array}{l}\text { Creating market space that does not yet } \\
\text { exist }\end{array}$ \\
\hline Win the competition & Make the competition irrelevant \\
\hline Exploiting existing requests & Creating and capturing new requests \\
\hline Conducting value-cost trade-offs & Breaking cost-value trade-offs \\
\hline $\begin{array}{l}\text { Integrating the entire system of company } \\
\text { activities with strategic choices between } \\
\text { differentiation or low cost }\end{array}$ & $\begin{array}{l}\text { Integrating the whole system of company } \\
\text { activities in pursuit of differentiation } \\
\text { and low cost [6] }\end{array}$ \\
\hline
\end{tabular}

The third principle is to reach beyond the existing demand, the purpose of this principle is that companies need to see or pay more attention to the non-consumer side sector which is divided into three levels of non-consumers. The fourth principle is to do the right set of 
strategies. This is intended for companies to create strong business models to generate profits from blue ocean design ideas. The last two principles are more at the implementation stage, namely strategy execution and integrating execution into strategy. In this principle, the company is expected to communicate strategy effectively and build trust and commitment to all employees. To facilitate understanding between blue ocean strategy and red ocean strategy, Table 1 will show the difference between the two.

\subsubsection{Value Innovation}

Value innovation is one way to create a blue ocean strategy. This emphasizes value equality and innovation. In this case, value innovation is defined as a new way to think about and implement a strategy towards creating a blue ocean strategy and leaving the competition arena. In general, companies are faced with two choices: create a higher value but at a certain cost (differentiation) or create a certain value at a lower cost (cost leadership). This contrasts with the application of value innovation, where the company does not choose one option but tries to carry out a differentiation strategy and cost leadership simultaneously. By offering value innovation, companies will benefit from the influence of cost structures and value offerings to consumers. The value received by consumers will increase by creating or adding elements that are not yet offered by the company.

The achievement of value innovation applied by the company is occurred when there is integration between the utility, price, and cost. In the other words, it is occurred when consumer value is generated from the utility and price offered by the company, and the value of the company is generated by the price and cost structure of the product produced (Fig 1). Therefore, companies must also expand market boundaries to non-consumers. Value innovation is created when actions taken are affecting the cost structure and value proposition for buyers. Cost savings measures are carried out by eliminating and reducing factors points of competition in an industry. Consumer value increase by adding or even creating elements that have never been offered by the industry. As time goes by, the costs incurred are decreasing due to the increasing sales volume by producing superior value for the products produced.

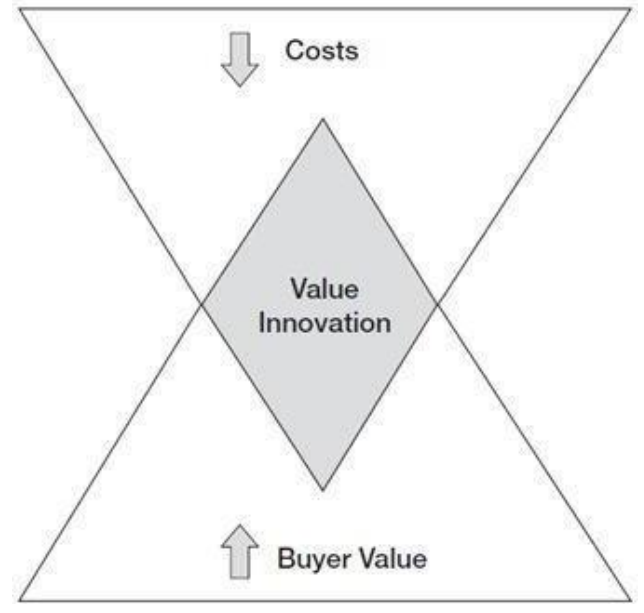

Fig 1. Value Innovation [6]

In maximizing the formulation of a blue ocean strategy, companies must be able to take the opposite path of Red Ocean, which is by not concentrating on consumers, but paying more attention to non-consumer markets. In this case, it is necessary to develop what 
buyers want in general. Thus, it is expected that the company will be able to reach beyond the existing demand and create market to new consumers that did not exist before. There are three levels of non-consumers, i) those who are close to the market, ii) those who reject the purchase of offers or products from the industry, and iii) those who are furthest from an industry's market.

\section{Research Method}

\subsection{Time and Location}

This research applied a mixed research method, by applying exploratory sequential mixed method. The research is conducted at PT Alam Indah Bunga Nusantara (PT Alinda) which is located at Jalan Mariwati km 5 Kawungluwuk Village, Sukaresmi Cipanas District, Cianjur Regency, West Java 43254. The selection of research locations was carried out purposively with the consideration that PT Alinda had been running Chrysantemum business since 1989. In addition, PT Alinda is also located in the highest production district of cut Chrysanthemum in West Java, Cianjur. Moreover, the company surrounded by other 46 companies competing in the ornamental plants industry [5]. The research is conducted since late 2018 - January 2020.

\subsection{Data Collection}

Data used in this study is combination between primary and secondary data. Primary data were obtained through interviews related stakeholders such as General Manager, Production Manager, Marketing Manager, Finance Division, Department of Agriculture of Cianjur Regency, consumers of PT Alinda, and non-consumer respondents. Secondary data is obtained from literature studies of previous research, books, journals, online articles, or mass media that are relevant to the research the author is doing. This study uses a questionnaire instrument to determine the main factors that are taken into consideration by respondents in selling or buying Chrysanthemums (competition factors), as well as interviews with the company to obtain company profile data to create blue ocean strategy opportunities.

The method used in determining the sample in this study is non-probability sampling. Respondents are selected based on their expertise or role at the company. Therefore, interview respondents and questionnaires in this study were chosen based on the consideration that the respondents were parties related to the research and understood about chrysanthemum flowers. In a qualitative study, only a small sample of people, groups, or events is selected without exception, in the context of the in-depth nature of the study [7]. For this reason, respondents who were selected for qualitative data collection were purposively selected. Furthermore, respondents selected for quantitative data collection are divided into two categories, i) consumers and non-consumers, and ii) consumers of PT Alinda who has purchased Chrysanthemum flowers at PT Alinda and also competitors.

Respondents obtained in the first category are 45 people, consisting of 30 people as consumers and 15 people as non-consumers. All these respondents had previously carried out purchasing activities of Chrysanthemums in Cianjur Regency, where 15 of the 45 have purchased Chrysanthemum flowers at PT Alinda. The number of sample determinations refers to the book Research Methods For Business which states that in research the appropriate sample size to use is between 30 to 500 [8]. In addition, the minimum number of samples suitable for use in research is 30 people [9]. The number of respondents in the 
second category is 12 , are florists or traders. Data collection techniques carried out through interviews, literature studies, and questionnaires.

\subsection{Data Processing and analysis}

Data processing in this study was carried out using exploratory sequential mixed methods. The study begins by collecting data on purchase factors of Chrysanthemum consumers in Cianjur Regency as a based-on questionnaire construction. Further, the quantitative data that has been collected is then tested for validity using the Cochran Test and then validated to the management. This research uses triangulation techniques to test the validity of the data obtained through validation to the company management. The analytical tools used in formulating a blue ocean strategy consist of mapping the industry situation, a six-way framework, a four-step framework, and a series of testing blue ocean strategy ideas.

\subsubsection{Industry mapping}

Mapping the industrial situation aims to identify what factors are considered by buyers (consumers) in purchasing Chrysanthemums in Cianjur Regency and asses the company's performance factors in compared to competing companies by describing them through a strategy canvas. The strategy canvas for mapping the industry situation aims to summarize the current industry situation, understand the current competitive situation, and understand what consumers get from offerings made to the market. In the strategy canvas there are two axes that are used to read the conditions that occur. The horizontal axis on the strategy canvas is used to show the factors that become the arena of competition in an industry. The vertical axis on the strategy canvas is used to assess the level of supply that consumers provide to the industry. If the company has a high score on one of the factors of competition, then the company offers more to customers.

The information obtained will be tested for validity using the Cochran Test, after obtaining valid factors, and then the questionnaire is distributed again to category two consumers to be given an assessment of PT Alinda's performance factor with competitors. The data obtained will later be calculated the average value to determine the assessment on the vertical axis of the strategy canvas. After the value curve can be mapped in the strategic canvas, the situation of the cut chrysanthemum industry in Cianjur Regency can be identified. These results can then be used to see the strategic profile of each Chrysanthemum business actor, as well as a basis to see the condition of the competitive situation in the chrysanthemum industry in Cianjur Regency. Moreover, Cochran test was conducted to get the competition factors that are considered valid (valid) for consumers in making purchasing decisions, in this case the purchase of cut Chrysanthemums [10].

\subsubsection{Cochran test}

Cochran test is used to test the validity of the factors that have been identified from previous research, combined with the results of discussions with the Departement of Agriculture, Cianjur and also results of brainstorming process with the company. So, by using the Cochran test, the author will select the competitive factors in the Chrysanthemum industry and get the competition factors that are considered valid for consumers in making purchasing decisions, in this case the purchase of Chrysanthemums [11].

$$
Q=\frac{C(C-1) \sum C_{j}^{2}-(C-1) N^{2}}{C N-\sum R_{i}^{2}}
$$


Note:

$\mathrm{Q} \quad=$ Validity Index

$\mathrm{C} \quad$ number of variable (product atribut)

$\mathrm{Ri}=$ number of 'Yes' row

$\mathrm{Cj} \quad=$ Number of 'Yes' column

$\mathrm{N}=$ total number of 'Yes' row

The hypotheses used in this study are as follow:

H0: possibility of 'Yes' answer is the same for all competition factors

H1: possibility of 'Yes' answer is different for all competition factors

If $\mathrm{Q}>\mathrm{X} 2$ table, then reject $\mathrm{H} 0$ which means that there is not enough evidence to accept $\mathrm{HO}$ and a second stage of testing is needed, for that it is necessary to reduce the tested factors by looking at the smallest amount of $\mathrm{Cj}$. If $\mathrm{Q}<\mathrm{X} 2$ table, then accept $\mathrm{H} 0$, meaning that the identified factors significantly affect the buyers of Chrysanthemum in Cianjur Regency.

\subsubsection{Ordinal scale and mean value}

The use of the ordinal scale in this study aims to describe the industry situation in determining the respondents' assessment of the company's performance on the identified competitive factors. Ordinal data is data that has a higher level than nominal data, in ordinal data there are levels. The following is the formula used:

$$
\mathrm{Q}_{\mathrm{X}}=\frac{\Sigma \mathrm{C}_{\mathrm{j}}}{\mathrm{N}}
$$

Note:

$\mathrm{Qx}=$ Average value on factor $\mathrm{x}$

$\mathrm{EC} \mathrm{j}=$ Total number of $\mathrm{x}$ factor performance appraisals from all respondents

$\mathrm{N}=$ Number of respondents

Next, the average value is mapped into an ordinal scale thus the interpretation could be clearer.

Interval $=($ Highest value - lowest value $) /$ Number of Classes $=(6-1) / 6=0.833$

Therefore, the interpretation of the average respondent's assessment from each factor assessed is as follows:
a. $1.00-1.83=$ very unsuitable
b. $1.84-2.67=$ not suitable
c. $2.68-3.50=$ quite inappropriate
d. $3.51-4.33=$ quite appropriate
e. $4.34-5.17=$ suitable
f. $5.18-6=$ very suitable

\subsubsection{Creation of a blue ocean strategy}

Six-path framework is carried out to identify attractive opportunities that lie in the blue ocean and aims to expand the market for purchasing Chrysanthemums at PT Alinda. The stages in the six-way framework consist of i) find alternative industries, ii) find strategic groups within the industry, iii) examine the buying chain, iv) examine complementary product and service offerings, v) examine emotional or functional appeal to buyers, and vi) examine appropriate time [6].

Next is to develop a four-step framework that aims to develop a strategic plan based on the strategy canvas that has been created. The four-step framework is as follow: 
a. Eliminate stage is a step in eliminating competitive factors that are taken for granted in the Chrysanthemum industry in Cianjur Regency.

b. Reduce stage is a step-in term of reducing performance on competitive factors to below the industry average.

c. Raise stage is a step to increase the competition factor to be above the industry average.

d. Create stage is a step to create factors that have not been offered by the Chrysanthemum industry in Cianjur Regency. The four-step framework can be seen in the figure below.

Testing the blue ocean strategy idea was carried out after carrying out a six-way framework and a four-step framework. At this testing stage, strategy adjustments are made to three elements that are prerequisites for a good strategy, namely focus, divergence, and having an attractive motto. If the company already has these three elements, then the strategy can be said to be effective. Furthermore, strategic adjustments are made to the purchase utility, price, cost, and adoption. The purpose of this adjustment is to ensure that the strategy that will be implemented can improve a more robust and sustainable. Adjustments made to purchasing utility, prices, costs, and adoption are made only by explaining how these adjustments can occur without further research being carried out at this stage. Below is a blue ocean strategy formulation scheme that will be carried out at PT Alinda.

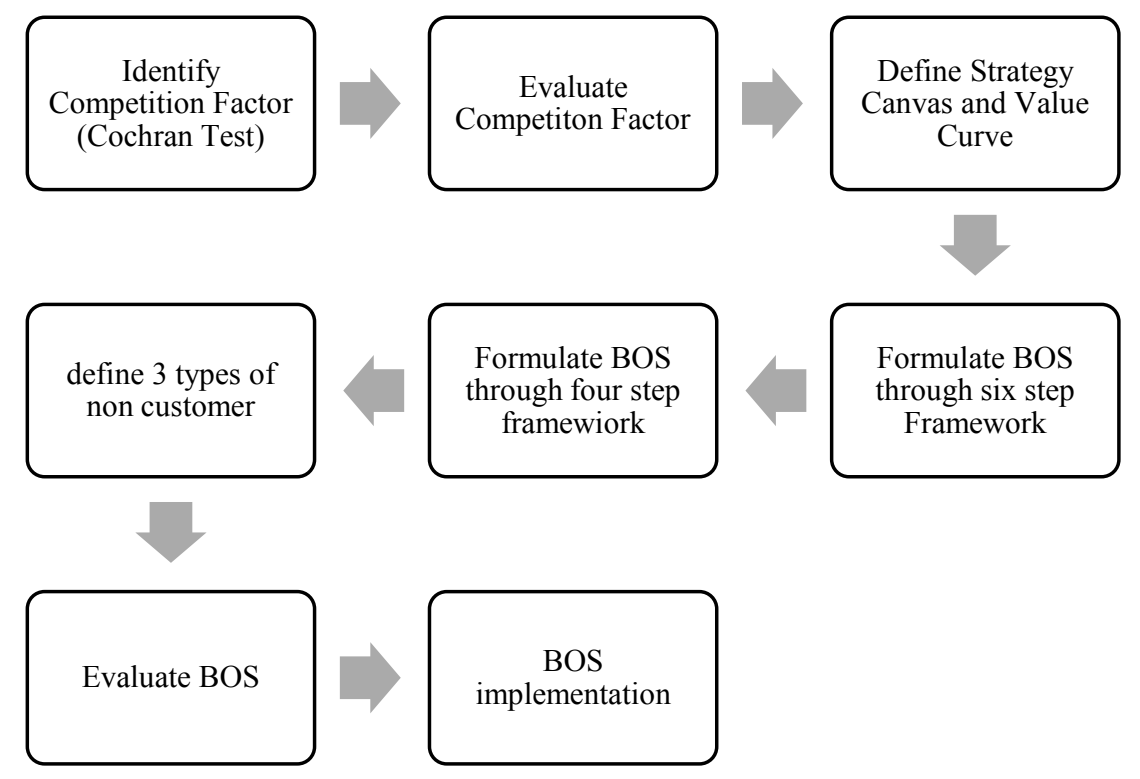

Fig. 2. Blue ocean strategy formulation scheme of PT Alinda

\section{Result and Discussions}

\subsection{Chrysanthemum industry analysis}

The flower industry referred in this study is an industry that involved companies or business actors who produce and market Chrysanthemum products. Each company in the industry has their own strategy to compete. Furthermore, the research also found that business actors in the Chrysanthemum industry are including both company and farmers. 
PT Alinda was established in November 1989 in Jakarta. PT Alinda's production area is divided into two plantations, namely PT Alam Indah Bunga Nusantara I and PT Alam Indah Bunga Nusantara II. The company is engaged in floriculture, where the scope of its business includes the cultivation of Chrysanthemums, potted Chrysanthemums, and filler leaves (filler leaves in flower arrangements). Among the products produced, Chrysanthemum is the main business commodity. The daily production capacity of Chrysanthemum reaches $250-300$ stalks for one plantation and reaches $1000-1,500$ stalks per day for both plantations. The cut Chrysanthemum cultivated by PT Alinda is divided into 2 types, the standard type, and the spray type. The standard type is a flower type that only has one large flower, while the spray type is a flower type that has several smaller flowers.

Considering previous study on Chrysanthemum and purchase factor analysis, this study assumes several relevant attributes which are also combined and been discussed with the company stakeholders. Similar study on orchid business resulting factors of competition that influence consumer purchasing decisions for orchids. Those factors are including price factors, plant quality, location, image, product diversification, service, and packaging [12]. Consumer preferences for Chrysanthemums and potted flowers is analyzed and it is founded that the main considerations for florist consumers in purchasing Chrysanthemum are flower type, flower colour, flower size, flower shape, flower stalk rigidity, flower resistance, and finally flower price [13]. In contrast to the type of potted chrysanthemum, the main considerations for consumers in buying Chrysanthemums are flower colour, flower shape, vase, flower size, flower rigidity, and flower price [13]. The desk study, observation and focus group discussion resulting 16 factors of competitions, which considered as influencing factor of customer purchase, those factors are including i) price, ii) pests and diseases free iii) rigidity of flower stalks, iv) diversity of colours and varieties, v) uniformity of flower size, vi) colour brightness, vii) durability, viii) promotion, ix) ease of ordering, x) payment negotiation service, xi) packaging, xii) speed of delivery, xiii) product quality assurance, xiv) flower trends in the market, xv) location, and xvi) image of business actors.

Information to determine the factors of competition in the cut Chrysanthemum industry in Cianjur Regency was obtained by distributing questionnaires to the first category of respondents, namely consumers and non-consumers. The competition factors proposed in the questionnaire for respondents use the form of a nominal scale, namely by only providing YES and NO answers. After the questionnaire was distributed, the results of the questionnaire were then tested for validity using the Cochran test. Tabel 2 shows the results of Chocran Test.

Tabel 2. Accepted competition factor based on chochran test

\begin{tabular}{|l|l|l|}
\hline No. & Competition Factor of Chrysantemum & Note \\
\hline 1. & Price & Factor A \\
\hline 2. & Pest and disease free & Factor B \\
\hline 3. & Colour brightness & Factor F \\
\hline 4. & Flower durability & Factor $\mathrm{G}$ \\
\hline 5. & Ease for order & Factor I \\
\hline 6. & Payment negotiation service & Factor J \\
\hline 7. & Product quality assurance & Factor M \\
\hline
\end{tabular}

Based on the table above, these factors are selected factors that are used as the main considerations for both consumers and non-consumers in purchasing Chrysanthemums in Cianjur District. In addition, these factors are also used as key factors in competing between Chrysanthemum business actors. The results of the selected factors will later be 
placed on the strategy canvas on the horizontal axis to find out the current industry situation between chrysanthemum business actors.

Table 3. Consumer's evaluation of PT Alinda's and competitors' competition factors

\begin{tabular}{|c|c|c|c|c|c|c|c|}
\hline $\begin{array}{c}\text { Business } \\
\text { Actor }\end{array}$ & \multicolumn{7}{|c|}{ Competition Factors in Chrysantemum Industry (interpretation, value) } \\
\cline { 2 - 8 } & $\begin{array}{c}\text { Price } \\
(\mathbf{A})\end{array}$ & $\begin{array}{c}\text { Pest \& } \\
\text { Disease } \\
\text { Free } \\
(\mathbf{B})\end{array}$ & $\begin{array}{c}\text { Colour } \\
\text { Brightness } \\
(\mathbf{F})\end{array}$ & $\begin{array}{c}\text { Durability } \\
(\mathbf{G})\end{array}$ & $\begin{array}{c}\text { Ease } \\
\text { for } \\
\text { Order } \\
(\mathbf{I})\end{array}$ & $\begin{array}{c}\text { Payment } \\
\text { Negotiation } \\
\text { Service } \\
(\mathbf{J})\end{array}$ & $\begin{array}{c}\text { Product } \\
\text { Quality } \\
\text { Assurancce } \\
(\mathbf{M})\end{array}$ \\
\hline PT Alinda & S & QA & VS & VS & QA & S & S \\
& 4.6 & 4.1 & 5.4 & 5.8 & 4 & 4.8 & 5.1 \\
\hline \multirow{2}{*}{ Competitor } & QA & QA & QA & QA & QA & QA & QA \\
\hline
\end{tabular}

Note:
a. $1.00-1.83=$ very unsuitable $(\mathrm{VU})$
b. $1.84-2.67=$ not suitable $(\mathrm{NS})$
c. $2.68-3.50=$ quite inappropriate $(\mathrm{QI})$
d. $3.51-4.33=$ quite appropriate $(\mathrm{QA})$
e. $4.34-5.17=$ suitable $(\mathrm{S})$
f. $5.18-6=$ very suitable (VS)

The strategy canvas in this study aims to provide an overview of the competition occurred by mapping the competition factors that have been established. Strategy canvas is important as basic information used to help map out company's future strategies. Company's strategy canvas illustrates the strategic profile of a company in one industry. Further, strategy canvas also identifies which factors are used as investment venues for them in the future. The strategy canvas was obtained from the second stage of questionnaire data given to the second category of respondents, namely consumers of PT Alam Indah Bunga Nusantara and its competitors. Most of PT Alinda's consumers are wholesaler and florist. The numbers of respondents questioned in this stage are 15 respondents. Strategy canvas images are connected by horizontal and vertical axes. The horizontal axis on the strategy canvas aims to show the competitive factors which have been validated through Cochran Test. The selected competition factors based on the Cochran Test are i) price factor, ii) pests and diseases free, iii) colour brightness, iv) flower durability, v) ease of ordering, vi) payment negotiation services, and vii) product quality assurance. The vertical axis on the strategy canvas shows the level of those factors for each business factor. To perform PT Alinda's and Chrysanthemum industry's strategy canvas, first the consumers' evaluation of those competition factors should be conducted. Table 3 shows the result of consumers' evaluation of those competition factors. The mean value is mapped into an ordinal scale range so it can be interpreted clearly and precisely.

The visualization of the consumer's evaluations on Table 3 can be seen in the Figure 3 below. The results obtained from Table 3 are the average value of the total assessment given to the second category of respondents. The scores obtained from each calculation are plotted on the vertical axis, while the horizontal axis represents the competition strategy. Figure 3 illustrates the position of competition factor evaluated by the consumers. The evaluation shows that PT Alinda has higher score in compared to competitors in several factors such as price factor (A), colour brightness factor $(\mathrm{F})$, durability factor $(\mathrm{G})$, payment negotiation service factor $(\mathrm{J})$ and product quality assurance factor $(\mathrm{M})$. In the other hand, pest and diseases free factor (B), ease for order factor (I) for PT Alinda evaluation score is founded below the competitor's score. 


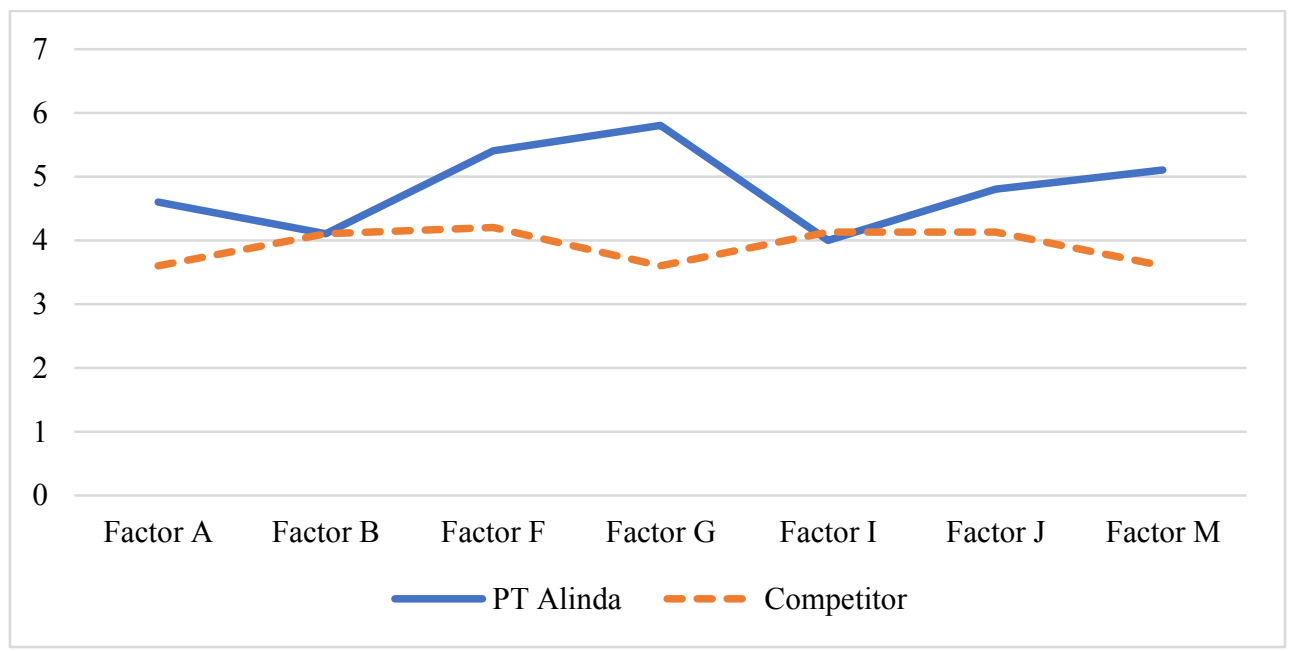

Fig 3. Strategy canvas of Chrysanthemum in Cianjur Regency

Note:

$\mathrm{A}=$ Price factor

$\mathrm{B}=$ Pest and diseases free factor

$\mathrm{F}=$ Colour brightness factor

$\mathrm{G}=$ Durability factor

$\mathrm{I}=$ Ease for order factor

$\mathrm{J}=$ Payment Negotiation service factor

$\mathrm{M}=$ Product quality assurance

There are several interpretations based on the situations found in Figure 4. First is that the conditions of companies which is trapped in the Red Ocean condition, will tend to have similar value with the competitors. In this case, the strategy applied by the company tends to focus on winning the competition through cost or quality focus. Based on the strategy canvas in Figure 4, PT Alinda's evaluation especially in factor of pest and disease free (B), the ease of ordering factor (I), the price negotiation service factor $(\mathrm{J})$, and the price factor (A) shows similar or even lower value in compared to the competitors. The pest and disease-free factor (B) and the ease of ordering factor (I) become the lowest scores of PT Alinda. This can be triggered by the close plantations area and very decisive weather conditions. Most of the area at PT Alinda is currently declining due to a long monoculture practice, this also affect the flower quality produced. Due to this situation, PT Alinda need to pay serious attention since the price offered by PT Alinda is relatively higher in compared to competitors. Further, the ease for ordering factor (I) also has a low score in compared to other factors. Based on observations and discussions with stakeholders it can be triggered by a more complex payment system in compared with the farmers as competitors. It is encouraged that PT Alinda could simplify the payment system and improves the services in purchasing. Overall, the performance factor of PT Alinda is mostly higher than the competitors, which indicates that the company is quite well in running business. Second implication of results on Figure 4 is the strategic contradiction, which is a condition where the company makes excessive bids, but the results obtained are inadequate. Companies make high-level bids on a competitive factor but ignore other areas that support that factor. This can be seen in the value curve of PT Alinda and the competitors where PT Alinda makes a high offer on product quality, especially on the colour brightness factor (F) and the flower durability factor $(\mathrm{G})$. But on the other hand, on the ease of ordering factor (I), the performance level is low. This could inhibit purchase activity of consumers. 


\subsection{Formulation of blue ocean strategy}

In creating a blue ocean, PT Alinda needs to reconstruct the market boundaries of current Chrysanthemum industry. This reconstruction aims to create a market space that has not been touched and there are no competitors in the industry, to minimize the risk of companies falling into the red ocean. There are six principles to encourage the implementation of a blue ocean strategy, but only four of them are the main basis for formulating a blue ocean strategy. The principles in formulating a blue ocean strategy include (1) reconstructing market boundaries, (2) focusing on the big picture, not on numbers, (3) reaching beyond existing demand, and (4) executing the right strategic sequence [6].

Table 4. The six path framework of Chrysanthemum business

\begin{tabular}{|c|l|l|}
\hline No. & Six Path Framework & \multicolumn{1}{|c|}{ Note } \\
\hline 1. & $\begin{array}{l}\text { Observe alternative } \\
\text { industries }\end{array}$ & $\begin{array}{l}\text { Alternative industries for Chrysanthemums are the } \\
\text { decorative handicraft industry made from waste, the } \\
\text { handicraft industry, the plastic/paper/flanel flower } \\
\text { industry, the flower arrangement industry, or other cut } \\
\text { flower industries. }\end{array}$ \\
\hline 2. & $\begin{array}{l}\text { Observe strategic } \\
\text { groups }\end{array}$ & $\begin{array}{l}\text { The strategic groups in the Chrysanthemum industry } \\
\text { besides florists are individual consumers, hotels, } \\
\text { restaurants, and decorators. }\end{array}$ \\
\hline 3. & $\begin{array}{l}\text { Observe the consumer } \\
\text { chain }\end{array}$ & $\begin{array}{l}\text { PT Alinda - Florist - End User, becomes } \\
\text { PT Alinda - End User. }\end{array}$ \\
\hline 4. & $\begin{array}{l}\text { Observe } \\
\text { complementary } \\
\text { product and service } \\
\text { offers }\end{array}$ & $\begin{array}{l}\text { Improving the performance of the company's website } \\
\text { which has not been maximized, and utilizing social } \\
\text { media such as Instagram, Facebook, or Twitter as a } \\
\text { means of promotion. }\end{array}$ \\
\hline 5. & $\begin{array}{l}\text { Observe emotional- } \\
\text { functional } \\
\text { attractiveness }\end{array}$ & $\begin{array}{l}\text { Create a tourism service program (agrotourism) for } \\
\text { consumers and non-consumers. }\end{array}$ \\
\hline 6. & $\begin{array}{l}\text { Perfect timing } \\
\text { Choosing varieties that do not yet exist in Indonesia, and } \\
\text { making processed products from chrysanthemum plants. }\end{array}$ \\
\hline
\end{tabular}

From each of the principles mentioned above, each has a different analytical tool. But overall, the principles aim to be able to create a value innovation and make the competition irrelevant, as well as create a leap in value that is obtained by the buyer as well as the company. This value innovation creation is used as a basic way to be able to find new unexplored market space so that it has profitable growth opportunities. The following is an explanation and analysis of the stages of creating a blue ocean to be recommended to PT Alam Indah Bunga Nusantara. The first principle is to create a blue ocean strategy is to reconstruct market boundaries. On this principle, the company strives to stay away from the competition and create a blue ocean. The challenge that needs to be faced in creating the first principle is to identify possibilities or interesting opportunities that exist to be commercialized. There are six approaches that can be used in reshaping market boundaries, called the Six Paths Framework [6]. The six-path framework focuses on looking at alternative industries, strategic groups, buyer chains, complementary product and service offerings, industry-emotional functional orientation, and timing. Table 4 shows the results of the analysis and explanation of the six-path framework.

Furthermore, the formulation of the blue ocean strategy that has been discussed using the six-path framework is continuing with the next analysis called four-step framework. 
The four-step framework is summarized into Eliminate - Reduce - Raise - Create. Table 5 summarizes PT Alinda's four-step framework.

Table 5. The four-step framework of Chrysanthemum business

\begin{tabular}{|c|c|}
\hline Four Step Framework & Note \\
\hline Eliminate & Payment negotiation service factor $(\mathrm{J})$ \\
\hline Reduce & Product quality assurance (M \\
\hline Raise & $\begin{array}{l}\text { Ease of order factor }(\mathrm{I}) \\
\text { Pests and diseases free factor }(\mathrm{B})\end{array}$ \\
\hline Create & $\begin{array}{l}\text { Factors for ordering flower arrangements in the form of } \\
\text { buckets or flower boards (1) } \\
\text { Dried flower craft factor (2) } \\
\text { Supporting service facilities factor(3) } \\
\text { Product diversification factor (processed products) (4) }\end{array}$ \\
\hline
\end{tabular}

\subsection{New strategy canvas for PT Alinda}

Based on the results of the six-path framework and analysis of four-step framework, the next step is to create a new (future) strategy canvas for PT Alam Indah Bunga Nusantara. The creation of this new strategy canvas still refers to the previous strategy canvas, which will be reconstructed. PT Alinda's strategic profile on this new canvas is made according to the three characteristics of a good blue ocean idea. The new and future assessment factors for PT Alam Indah Bunga Nusantara can be seen in the Table 6.

Table 6. New assessment of PT Alinda's competitive factors

\begin{tabular}{|c|c|c|c|c|c|c|c|c|c|c|c|}
\hline \multirow{2}{*}{$\begin{array}{l}\text { Business } \\
\text { actor }\end{array}$} & \multicolumn{11}{|c|}{ Competition Factors } \\
\hline & $\mathbf{A}$ & B & $\mathbf{F}$ & $\mathbf{G}$ & I & $\mathbf{J}$ & $\mathbf{M}$ & 1 & 2 & 3 & 4 \\
\hline PT Alinda & 4.6 & 5 & 5.4 & 5.8 & 5 & 0 & 3 & 4 & 4 & 4 & 4 \\
\hline Industry & 3.6 & 4.1 & 4.2 & 3.6 & 4.13 & 4.13 & 3.6 & 0 & 0 & 0 & 0 \\
\hline
\end{tabular}

A study of consumer preference of Chrysanthemum found that the combination of attributes that is most interested in consumers and chrysanthemum cut flower sellers are quality factors and product specification factors. The quality factors are included flower resistance, stem rigidity, and flower freshness, while the specification factors are included colours, and also other specification factors such as aesthetics, and price [14, 15]. Further, other found that pest, disease, and weather are risk factors that become most influenced the Chrysanthemum production [16]. Those findings support the new competitive factors of PT Alinda that confirmed some similar factors such as factor A, B, F, G, I, J and M. Moreover, blue ocean strategy analysis of PT Alinda has also resulted new competition factors including flower arrangements (bouquets or flower boards) (1), dried flower craft factors (2), supporting service facilities factors (3), and product diversification factors (processed products) (4). This new factor is expected to form a unique and different picture from PT Alinda competitors, as characterized by the blue ocean strategy. The visualization of the new strategy canvas for PT Alinda can be seen in the Figure 4.

The next step in achieving value innovation to formulate a blue ocean strategy is to look at new potential, non-consumer markets. There are three levels of non-consumers who may be converted into consumers [6]. Observing these three levels of non-consumers is also a part of reconstructing market boundaries process. The first tier of non-customers is those closest to your market, whose purchases is encouraged out of necessity, they are customers who buy Chrysanthemums only because of the need for decoration, the means of expressing feeling, occasional buying (graduation, birthdays, religious events, state events, and others). 


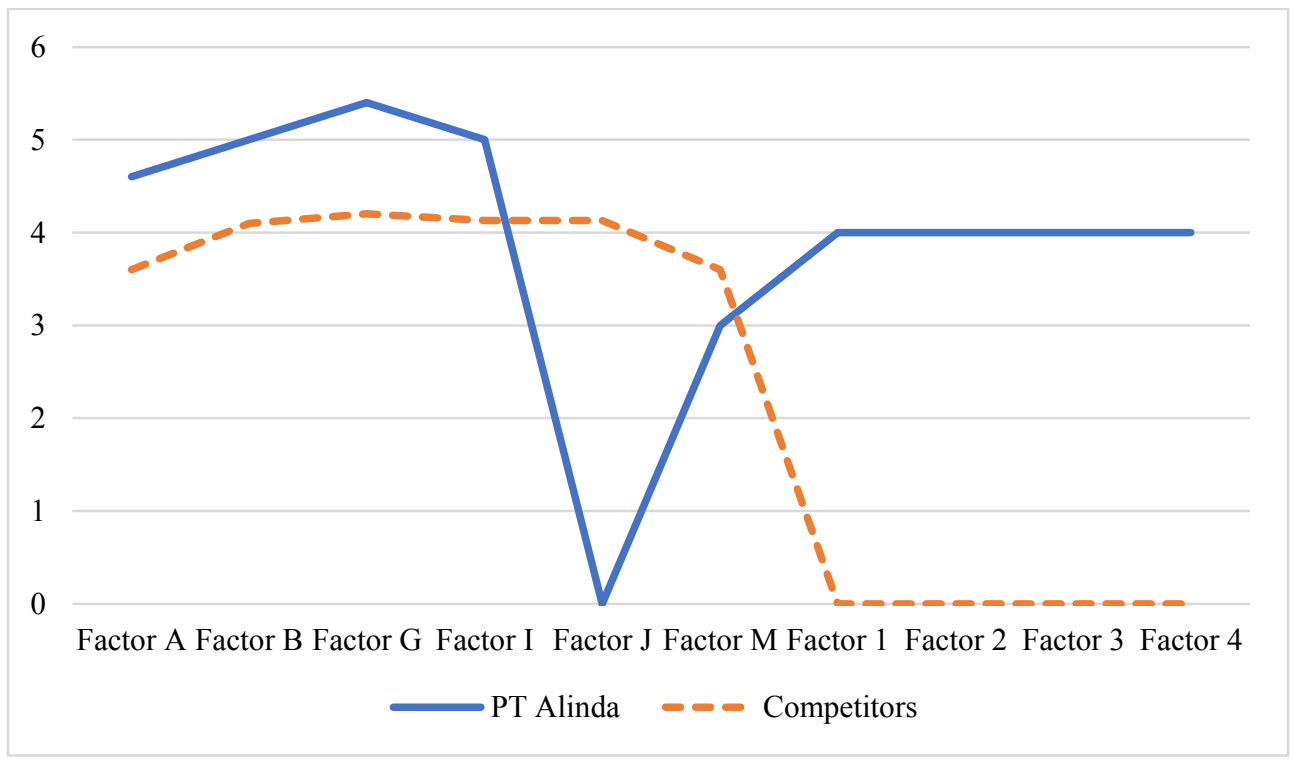

Fig. 4. New strategy canvas of Chrysanthemum in PT Alinda

Information:

$\mathrm{A}=$ Price factor

$\mathrm{B}=$ Pest and disease-free factor

$\mathrm{F}=$ Colour brightness factor

$\mathrm{G}=$ Flower durability factor

$\mathrm{I}=$ Ease of ordering factor

$\mathrm{J}=$ Payment negotiation service factor

$\mathrm{M}=$ Product quality assurance factor

$1=$ Flower arrangement ordering factor

$2=$ Dried flower craft factor

$3=$ Supporting service facilities factor

$4=$ Product diversification factor (processed products)

Moreover, the third tiers of non-customers are those who are furthest from the market. They are non-customers who never thought that Chrysanthemum industry offerings them an option. They are people who do not make purchases of all kinds of Chrysanthemums, for example, consumers who buy flowers for burial will use cut flowers of red and white roses and rarely use chrysanthemums. By focusing on the key similarities between these levels of non-customers and among existing customers, companies can understand how to attract these potential customers into new markets. The main commonalities of these nonconsumers are those who want something to be used as a means of expressing feeling or as a decoration for the surrounding environment, affordable prices, and can be owned for a long period of time. With these similarities, it is hoped that non-consumers of Chrysanthemum flowers can turn into consumers of PT Alinda.

Finally, to construct a blue ocean strategy, three basic elements of focus, divergence, and an attractive motto must be considered. The focus in the formulation of this strategy is on enhancing the low-value competitive factors, as well as the new factors that have been created in the expansion of marketing activities. Focusing on factors that have low ratings and the new factors that have been created at PT Alinda will encourage new value curve differ from competitors. Thus, PT Alinda's strategy will meet the criteria for divergence (moving away). Another criterion that must be possessed in formulating a good strategy is to have a strong and compelling motto. Previously, PT Alinda's motto is "flowers are the perfect gift, just a simple thank you". However, this motto is not communicated to 
consumers and is only displayed on the vehicle box used for flower delivery. For this reason, a new motto is needed to reflect the formulated strategy. The alluring motto that will be used is "say everything with flowers, everyday". This motto is formed from the formulation of the blue ocean strategy that has been discussed previously, where the recommended strategy is more directed to market expansion for direct users. The motto should be socialized more to the customer and attached in every company attribute.

\section{Conclusion}

Implementation of PT Alinda's blue ocean strategy is started by first reconstructing the market boundaries, where company identifies new opportunities offered to consumers. The study resulting several new opportunities including creating new business line in flower arrangement industry, dried flower decorations. Moreover, sales are also enhance by targeting new groups of have not been touched buyers (decorators, hotels, restaurants, direct consumers), improving media performance, the creation of tourism services, as well as making processed Chrysanthemum products.

Second step is to rebuild the buyer value elements on the competitive factors. The elements that must be rebuilt are 1) eliminating the payment negotiation service factor, 2) reducing the product quality assurance factor, 3) raising the ease of ordering factor and being free of pests and diseases, as well as 4) creating the ordering factor for flower arrangements, dried flower crafts, supporting service factors (tourism services), and creating processed product factors.

The third step is maximizing the new strategy formulation for the non-consumer market. The consumer level in this step is the first non-consumer level (decorators, flower consumers for graduation events, birthdays, religious events, etc.), the second nonconsumer level (other cut flower consumers, handicraft or ornamental consumers), noncustomer levels. The third tier consumers are those who have never thought of using the Chrysanthemum industry as an option.

The last step is testing a blue ocean strategy based on three good elements. First is to focus on improving low-performing factors and encouraging the succesful exécution of the new factors. Second is divergence, which can be achieved throug applying the new factors so that PT Alinda can be differ from competitors. Thisrd is promoting an alluring new motto, "Say everything with flowers, everyday". It is hoped that with this motto, new consumers can increase their purchase of flowers in PT Alinda.

\section{References}

1. F. A. Putri, S. S. Putri, R. Yulianti, S. I. Sifa, Khazanah J. Mhs. 12, 1 (2020).

2. M. A. L. Sihombing, A. M. C. Rohie, N. Februyani, R. E. Swandayani, J. Indones. Tour. Dev. Stud. 3, 19 (2015).

3. Badan Pusat Statistik, Statistik Tanaman Hias Indonesia (2018).

4. Direktorat Jenderal Hortikultura, Statistik Produksi Hortikultura Tahun 2014 (2015)

5. Balai Pengembangan Budidaya Tanaman Pangan dan Hortikultura Kabupaten Cianjur, Pelaku Usaha Tanaman Hias di Kabupaten Cianjur (2016)

6. W. C. Kim, R. Mauborgne, Blue Ocean Strategy, (Harvard Business School Publication Coorperation, 2015)

7. U. Sekaran, Metodologi Penelitian untuk Bisnis, (Salemba Empat, Jakarta, 2006)

8. Sugiyono, Metode Penelitian Kuantitatif Kualitatif Dan R\&D, (CV Alfabeta, Bandung, 2004) 
9. M. Singarimbun, Metode Penelitian Survei, (Lembaga Penelitian, Pendidikan, dan Penerangan Ekonomi dan Sosial, Jakarta, 1995)

10. D. Durito, T. Sitinjak, Sugiarto, Strategi Menaklukkan Pasar Melalui Riset Ekuitas dan Perilaku Merek, (PT Gramedia Pustaka Utama, Jakarta, 2004)

11. V.W. Sujarweni, Metodologi Penelitian, (Pustaka Baru Press, 2014)

12. H.A. Pradana,Y. Risanto, Penerapan Blue Ocean Strategy pada Bisnis Tanaman Anggrek (Studi pada Handoyo Budi Orchid Malang, (Fakultas Ekonomi dan Bisnis, Universitas Brawijaya, Malang, 2015)

13. Nurmalinda, N.Q. Hayati, J. Hort, 24 (4), 363-372. (2014)

14. L. Mualifah, Masyhuri, A, Suryantini, Faktor-Faktor Yang Mempengaruhi Preferensi Konsumen Pada Bunga Potong Krisan Di DIY, (Universitas Gajah Mada, Yogyakarta, 2021).

15. A. Wijayani, Muafi, and R. Sukwadi, J. Bus. Retail Manag. Res. 12, 69 (2017)

16. O. Novian, T. Sarianti, Analisis Risiko Produksi dan Preferensi Risiko Petani Bunga Krisan Potong di Kecamatan Pacet Kabupaten Cianjur, (Institut Pertanian Bogor, Bogor, 2017) 